\title{
Chlorophyll-a variability during positive IOD - the east season period in 2019 in Padang Sea, Indonesia
}

\author{
Dandi Arianto Pelly ${ }^{1}$, Muh Aris Marfai ${ }^{1 *}$, Evita Hanie Pangaribowo ${ }^{1}$, and Akhmad Fadholi ${ }^{2}$ \\ ${ }^{1}$ Faculty of Geography, Universitas Gadjah Mada, Indonesia \\ ${ }^{2}$ Indonesia Meteorological Agency (BMKG), Jakarta, Indonesia
}

\begin{abstract}
This study aimed to identify the effect of the positive Indian Ocean Dipole (IOD) phenomenon on the spatial, temporal distribution of chlorophyll-a concentrations in the East Season in Padang Sea in 2019. The method used in this research was the Kriging analysis method applied in oceanographic parameter satellite imagery extraction point data. By applying the method, we produced the maps of the spatial distribution variation of chlorophyll-a content and Sea Surface Temperature (SST). The data of IOD events in 2019 showed the occurrence of a strong positive IOD phenomenon that caused anomaly in the Sea Surface Temperature (SST) in Padang Sea. The interpretation of Aqua-Modis level 2 satellite image data showed that the sea surface temperature during the East Season was relatively cold, which was in the minimum temperature ranging from $18.5-22^{\circ} \mathrm{C}$ with a normal temperature condition of $28-29^{\circ} \mathrm{C}$. The minimum chlorophyll-a concentration in the East Season was $0.252 \mathrm{mg} / \mathrm{m} 3$; while the maximum value reached 18.5 $\mathrm{mg} / \mathrm{m} 3$. The distribution value of chlorophyll-a concentration was $1.028 \mathrm{mg} / \mathrm{m} 3$. The RMSe Cross Validation value obtained was 0.504 for SST and 0.363 for chlorophyll-a with a mean SST of -0.0005 and mean chlorophyll-a of -0.0039 .
\end{abstract}

\section{Introduction}

The northeast waters of Indian Ocean, including the western waters of Sumatra and south waters of Java which are tropical oceanic waters, generally have low chlorophyll-a concentrations [1]. However, in certain season periods, there will be an increase in the chlorophyll-a concentration in the oceanic waters closer to the coast [2]. The distribution of chlorophyll-a concentration that is high in the coastal waters is due to a high nutrient supply coming from the mainland through the river water runoff; while the distribution tends to be low in offshore areas due to the absence of direct onshore nutrient supply.

However, high chlorophyll-a concentrations are still found in areas far from land. It is caused by the process of water mass circulation that allows the transport of a number of nutrients from a certain place in the deep layer to the surface of the ocean [3]. This water mass enhancing process, known as the upwelling process, is a mass vacancy in the surface layer and must be replaced by water mass in the deep sea layer. It is due to the development of SST pattern [4], [5].

The upwelling system of southern Java and western Sumatra is the upwelling system of tropical eastern boundary. It is unique because it is driven by a typical Indian Ocean (monsoon) wind system (monsoon wind upwelling system). This upwelling only appears during the southeast monsoon in June-October [6]. Thus, in general, the waters of western Sumatra and southern Java-Sumbawa might have different spatial and temporal chlorophyll-a distribution patterns. The difference is due to the monsoon winds that blow over these waters always change based on the season [7].

The close interaction between air and sea causes oceanic circulation in the Indian Ocean to be very closely related to the monsoon circulation that blows over these waters. This monsoon occurs due to changes in the sun position, which causes changes in pressure in the northern continent (Asia) and the southern continent (Australia). Besides, the movements of Equatorial Pressure Trough (EPT) and changes in the wind direction also have an influence in this wind movement. According to Wyrtky [8], the East monsoon occurs because a valley of low air pressure occurs over Asia and a peak of high air pressure above Australia which causes winds to blow from Australia to Asia.

The strong positive IOD phenomenon that occurred in 2019 had a large impact on the atmospheric and environmental conditions in Padang Sea. One of the impacts was the formation of intense and large upwelling area in the southwest regions of Sumatra and southern regions of Java. The variability of sea surface temperature anomalies and the strong upwelling phenomenon in the waters of the eastern Indian Ocean are closely related to the IOD phenomenon [6].

The strong positive IOD event is a climate anomaly that can disrupt the monsoon wind system in the western waters of Sumatra and southern waters of Java. By this perspective, this study aims to identify the positive IOD effect on the spatial temporal Chlorophyll-a

\footnotetext{
* Corresponding author: arismarfai@ugm.ac.id
} 
concentration distribution and value variability in Padang Sea during the east monsoon period in 2019.

\section{Methodology}

\subsection{Research locations}

The research location was in Padang Sea West Sumatra (Figure 1). Padang was a large port city on the west coast of Sumatra, which was the centre of the Indonesian Fisheries Management Area in the Eastern Indian Ocean region. The waters of Padang Sea laid in an astronomical position 100'3'16'E - $0^{\circ} 48^{\prime} 53$ 'S and 100'24'47'E $1^{\circ} 9$ '51'S; while the research area was $90,327.58$ hectares.

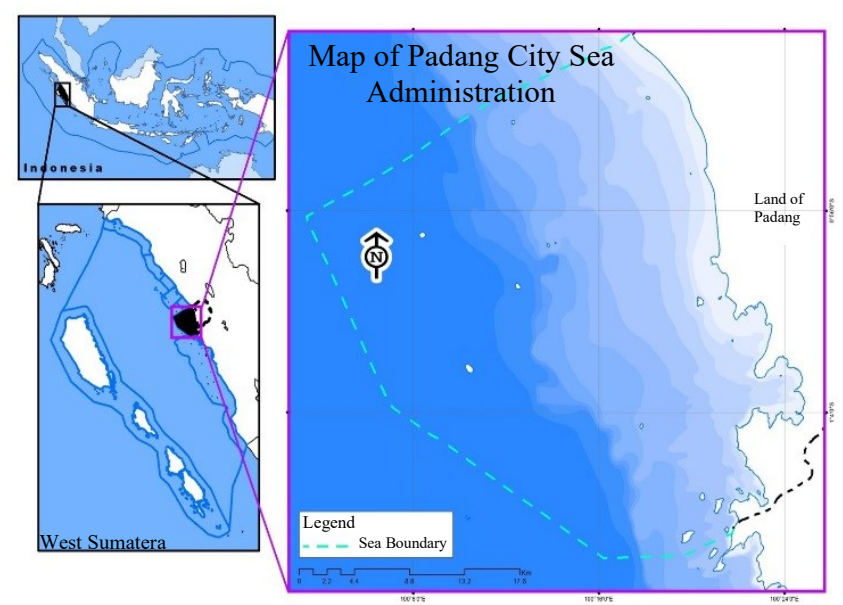

Fig. 1. Map of the Research Location in the Waters Area of Padang (Padang Sea)

\subsection{Data sources}

The data in this study were Aqua-Modis level 2 satellite images of chlorophyll-a concentration with spatial resolution of $1 \mathrm{Km}$ and SST condition extraction. The images were taken during the east season period, from the end of June to the end of September 2019. We downloaded them, in the NetCDF data format, on the website NASA Oceancolor. At the level 2, Aqua MODIS imagery products had data that contained geophysical values of an earth object which had passed the process of sensor calibration, atmospheric correction, and algorithms. In addition, the spatial resolution of $1 \mathrm{Km}$ was sufficient to analyse the primary productivity of large-scale waters. The NetCDF data processing method of Aqua MODIS level 2 used the SeaDAS 7.53 software to get the extraction value of SST conditions and chlorophyll-a concentration. The images displaying Padang Sea should be cropped and converted to the Shapefile data in the form of points to be able to input into GIS and later be processed spatially.

The analytical method in this study used geostatistics with the Kriging method interpolation to determine the spatial distribution of areas with chlorophyll-a concentrations at certain times. According to Montero, Avilés, and Mateu [9], Kriging was a better spatial interpolation technique than others (inverse distance method, splines, regression polynomial, and others). The Kriging interpolation takes into account not only the geometrical characteristics and the number and location organization, but also the spatial correlation structure inferred from the availability of semivariogram structure information, thus producing more reliably spatial and temporal spatial predictions. The prediction models of Kriging method interpolation were tested for accuracy and error investigations using cross validation. Cross validation was the part of statistical method that could be used to evaluate the model or algorithm performance while maintaining the estimate accuracy.

\section{Results and Discussion}

\subsection{Effect of Positive IOD on SST anomalies}

SST values during the east monsoon were changed, as the east monsoon winds from the cold Australian continent moved towards the hot Asian Continent across Indonesia. This phenomenon, occurring between April and October 2019, included in the relatively cold category whose the average temperature ranged from $18.5-22^{\circ} \mathrm{C}$; while the normal temperature was $28-29^{\circ} \mathrm{C}$. In August to early September, the Sun position was back on the Equator. The sun movement should cause SST to rise again, as a sign of the end of east season and the start of a new season which was the Eastern Transition Season. The movement caused winds from Australia to move north again towards the warmer inland waters and meet the winds from Asia that also went to Indonesia. However, there was an anomaly in temperature in 2019.

The phenomenon of dry-phase Indian Ocean Dipole (IOD) or positive IOD was an anomaly originating from the Indian Ocean. It was also referred to as a climate phenomenon that affected or disrupted the monsoon wind system, causing climate anomalies in the western and southern water areas of Sumatra and Java respectively. The eastern tropical Indian Ocean, in particular the west coast of Sumatra including Padang Sea experienced extensive cooling of SST (Figure 2) during the final months of the Australian winter (JulySeptember). The SST anomaly during the cooling phase was proportional to what was triggered by ENSO in the eastern Pacific around the equator. The Temperature was more than $2^{\circ} \mathrm{C}$, with a spatial area of $200 \mathrm{~km}$ to 600 $\mathrm{km}$ and duration of less than 3 months [10].

In addition, the temperature anomaly probably occurred due to the influence of smog getting thicker at the end of the east season, namely in early September, which should maintain a hot temperature. Radiation that came and stayed on the Earth surface was less than usual. Misty conditions changed the radiation transfer, that led to an increase in the sunlight reflection on the fog layer surface and a decrease or cooling of radiation surface [11].

The interpretation of Aqua-Modis level 2 satellite image data showed that SST in Padang Sea also tended to be high around the coast. This was due to the large intensity of sunlight radiation falling in the waters close to the equator. As explained by Simpson [12] and Lambert \& Webb [13], specific differences in land and sea heat capacity were affected by solar radiation and differences in the ability of land and sea to absorb and release such radiation. 


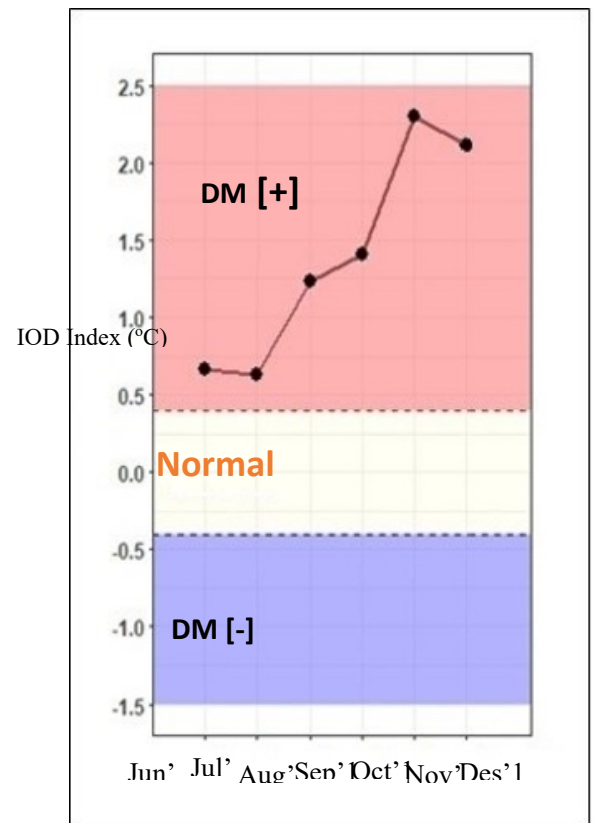

Fig. 2. Period of positive IOD event 2019 (Source: Indonesian Meteorological Agency)

The peak of the eastern monsoon occurred in July when the sun began to move from the northern hemisphere towards the equator. Under normal circumstances, the variability of SST values increased spatially, so that sea surface temperatures that were not too high spread evenly in all areas of Padang Sea. This was caused by the sunlight intensity received in all western water areas of Sumatra that was relatively the same. In the shallow sea waters close to the coast, the temperature was hotter, which was up to $34.58^{\circ} \mathrm{C}$. Meanwhile, in the open water area until the water area whose depths were more than $100 \mathrm{~m}$, SST was around $29^{\circ} \mathrm{C}$. Spatial distribution of Sea Surface Temperature $\left({ }^{\circ} \mathrm{C}\right)$ in Padang Sea during the east season in 2019 is presented in Figure 3.

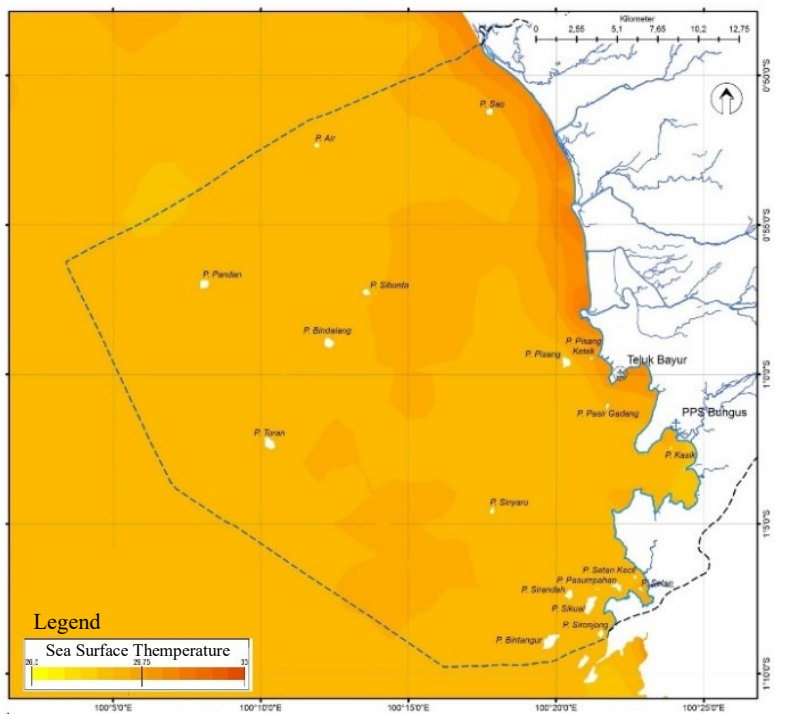

Fig. 3. Map of average SST $\left({ }^{\circ} \mathrm{C}\right)$ in Padang Sea during the east season in 2019

\subsection{Spatial and temporal distribution of Chlorophyll-a concentration}

Chlorophyll-a was one of the most important photosynthetic pigments for aquatic organisms. The main pigment content, it was found in phytoplankton organisms. There were four types of chlorophyll that were known to have phytoplankton, namely chlorophyll-a, chlorophyll-b, chlorophyll-c and chlorophyll-d. Furthermore, there were several other types of photosynthetic pigments; such as carotene and xanthophyll. Among these pigments, chlorophyll-a was the most common pigment found in phytoplankton. Therefore, phytoplankton concentrations were often expressed in chlorophyll-a concentrations [14].

Phytoplankton was a major contributor to primary productivity in the sea. Its presence was an indicator of water fertility [15]; [1]. The seasonal cycle of phytoplankton occurred in coastal areas. The species composition was very clean, and it was a primary productivity in the ocean. Therefore, the seasonal cycle of phytoplankton community influenced the entire community through trophic relations [16]. Chlorophylla was an important component supported by phytoplankton and aquatic plants, both of which were natural food sources for fish [17].

Variations in the distribution of chlorophyll-a concentrations in the water areas of Padang West Sumatra were influenced by many factors including the dynamics of water mass, their interactions with atmospheric conditions, and water depth. In general, water masses with an abundance of high chlorophyll-a content in Padang Sea were in shallow waters less than $100 \mathrm{~m}$ and close to the coast.

Interpolation of the distribution of chlorophyll-a from the extraction of Aqua-MODIS level 2 satellite image data from mid-June 2019 to mid-September 2019 resulted in variations in the concentration value of chlorophyll-a in Padang Sea. The average chlorophyll-a concentration at the beginning of the east season, which was at the end of June, in Padang Sea showed a range of values between $0.27-7.46 \mathrm{mg} / \mathrm{m} 3$. In this initial period, the average value of chlorophyll-a concentration was mostly $0.806 \mathrm{mg} / \mathrm{m} 3$, spreading almost evenly off the coast of Padang Sea. Maximum distribution of chlorophyll-a concentrations was found on the coast of Batang Arau river mouth and the area of Teluk Bayur Port. The minimum concentration at the end of June was still normal, which was $0.274 \mathrm{mg} / \mathrm{m} 3$ and found in the west of the Conservation Area of Pulau Pieh Tourism Park or outside Padang Sea (Figure 4).

The next period was in early July. The average chlorophyll-a concentration showed a range of values between $0.001-23.29 \mathrm{mg} / \mathrm{m} 3$. During this period, the average value of chlorophyll-a concentration was 0.75 $\mathrm{mg} / \mathrm{m} 3$ which spread evenly in the open waters of Padang Sea. Moreover, the high chlorophyll-a content began to be concentrated around the coast. The spatial distribution of chlorophyll-a in early July began to narrow from the end of June. At the end of July, the average chlorophyll-a concentration was between $0.1454-14.562 \mathrm{mg} / \mathrm{m} 3$ with an average chlorophyll-a concentration value of $0.5921 \mathrm{mg} / \mathrm{m} 3$. The high 
chlorophyll-a content extended from around the north coast to the south to Kabung Bay. Very high concentrations began to emerge around the Teluk Bayur Port (Figure 4).

During the early August period, the value of chlorophyll-a concentration averaged between 0.187 $10.43 \mathrm{mg} / \mathrm{m} 3$. The average distribution value of chlorophyll-a concentration was $0.635 \mathrm{mg} / \mathrm{m} 3$ which spread towards the northern waters. Meanwhile, high chlorophyll-a content was still seen around the estuary of Batang Arau and Teluk Bayur Port, with the situation starting to spread widely. The spatial distribution of chlorophyll-a at the end of August was highly concentrated around Muaro Penjalinan and Teluk Bayur Port with an average range of $0.0095-20.561 \mathrm{mg} / \mathrm{m} 3$. The average value of this period was $0.801 \mathrm{mg} / \mathrm{m} 3$.

In the end of the East Season in early September, the high chlorophyll-a content spread widely from south to north with high chlorophyll-a concentrations extending from the weaving estuary to north-western waters. The average concentration value was $0.26-20.56 \mathrm{mg} / \mathrm{m} 3$. In this period, the average value of chlorophyll-a concentration was higher than that in the previous period which was $1.36 \mathrm{mg} / \mathrm{m} 3$ (Figure 4). The high value of chlorophyll-a concentration in the ocean indicated the occurrence of the phenomenon of algal blooms in the ocean.

Chlorophyll-a concentrations at the peak of the east monsoon were the highest throughout the year under normal conditions. The distribution was more even with the range between the lowest and highest chlorophyll-a not too distinct. The abundance of chlorophyll-a marine nutrients in the east season in Padang sea was higher than that in other seasons. Throughout the season between late June and early September, nutrient concentrations continued to increase until the end of the east season in September.

Nutrient content from the mainland was not evenly distributed in Padang Sea, but it was concentrated in the area of Teluk Bayur Port and Padang Utara District, which was a meeting area of two major river mouths of Padang: Batang Kuranji River and Muaro Penjalinan River. In this water zone, the concentration of chlorophyll-a reached $20.56 \mathrm{mg} / \mathrm{m} 3$ with a fairly wide distribution. It made the range between the lowest chlorophyll-a concentration in deep waters more than $100 \mathrm{~m}$ with shallow waters became very long. In the deep waters of Padang Sea, the chlorophyll-a content in each volume of water was still normal, which was 0.26 $\mathrm{mg} / \mathrm{m} 3$.
In the end of east monsoon when the sun returned to the equator, the meeting of monsoons east from mainland Australia and southeast monsoons from mainland Asia revolved over the western coastal water area of Sumatra. The chlorophyll-a content at the end of the east season (September) which was still influenced by the southeast winds and currents from the east was very high. For more details, the average value of chlorophyll-a concentration in 15 days in the East Season in Padang Sea during the study can be seen in Table 1.

Based on the results of chlorophyll-a data processing, during the east season, the average minimum and maximum chlorophyll-a concentrations occurred in early July. As for chlorophyll-a, the lowest average occurred at the end of August and the highest occurred at the beginning of September. Figure 4 is a map of the average chlorophyll-a concentration per 15 days in Padang Sea during the east season in 2019.

The minimum average value of chlorophyll-a concentration in the east season was $0.252 \mathrm{mg} / \mathrm{m} 3$; while the maximum value reached $18.5 \mathrm{mg} / \mathrm{m} 3$. The distribution value of chlorophyll-a concentration was $1.028 \mathrm{mg} / \mathrm{m} 3$ (Figure 5). The size of chlorophyll-a concentration was included in the Mesotrophic category which was quite extensive. This category was characterized by sufficiently clear water and moderate nutrient content. The content of chlorophyll-a concentration was very high around the river estuary including Hypereutrophic, which had experienced enrichment of nutrients in very large levels, the water conditions were less clear and often occurred algae bloom. Moreover, the high chlorophyll-a concentration content in Padang Sea was included in the Eutrophic category or waters that were rich in nutrients, so that algal plants grew well. Waters included in this category was a suitable location to find out the presence of fish with optimum temperature conditions.

According to Vollenweider et al. [18], there were four categories of chlorophyll-a content values based on the fertility of waters. They were content of less than 1 $\mathrm{mg} / \mathrm{m} 3$ included in the Oligotrophic category, content of $1-3 \mathrm{mg} / \mathrm{m} 3$ included in the Mesotrophic category, content of $3-5 \mathrm{mg} / \mathrm{m} 3$ included in the Eutrophic category, and content of more than $5 \mathrm{mg} / \mathrm{m} 3$ included in the Hypereutrophic category. In the absence of currents and fronts, the value of chlorophyll-a concentration in Padang Sea which was located in the area of open tropical oceanic waters tended to be low [1].

Table 1. Average Chlorophyll-a Concentration (mg/m3) per 15 days in the East Season in Padang Sea in 2019.

\begin{tabular}{lrrr}
\hline East Season Period & $\begin{array}{c}\text { Minimum } \\
\text { Chlorophyll-a }\end{array}$ & $\begin{array}{c}\text { Maximum } \\
\text { Chlorophyll-a }\end{array}$ & $\begin{array}{c}\text { Average } \\
\text { Chlorophyll-a }\end{array}$ \\
\hline End of June & 0.274 & 7.456 & 0.8064 \\
\hline Beginning of July & 0.001 & 23.287 & 0.7499 \\
\hline End of July & 0.1454 & 14.562 & 0.5921 \\
\hline Beginning of & 0.187 & 10.43 & 0.635 \\
\hline End of Agustus & 0.0095 & 20.561 & 0.8007 \\
\hline Beginning of & 0.2637 & 20.562 & 1.3599 \\
\hline
\end{tabular}

Source: Chlorophyll-a data processing of Aqua MODIS Level 2 satellite imagery 

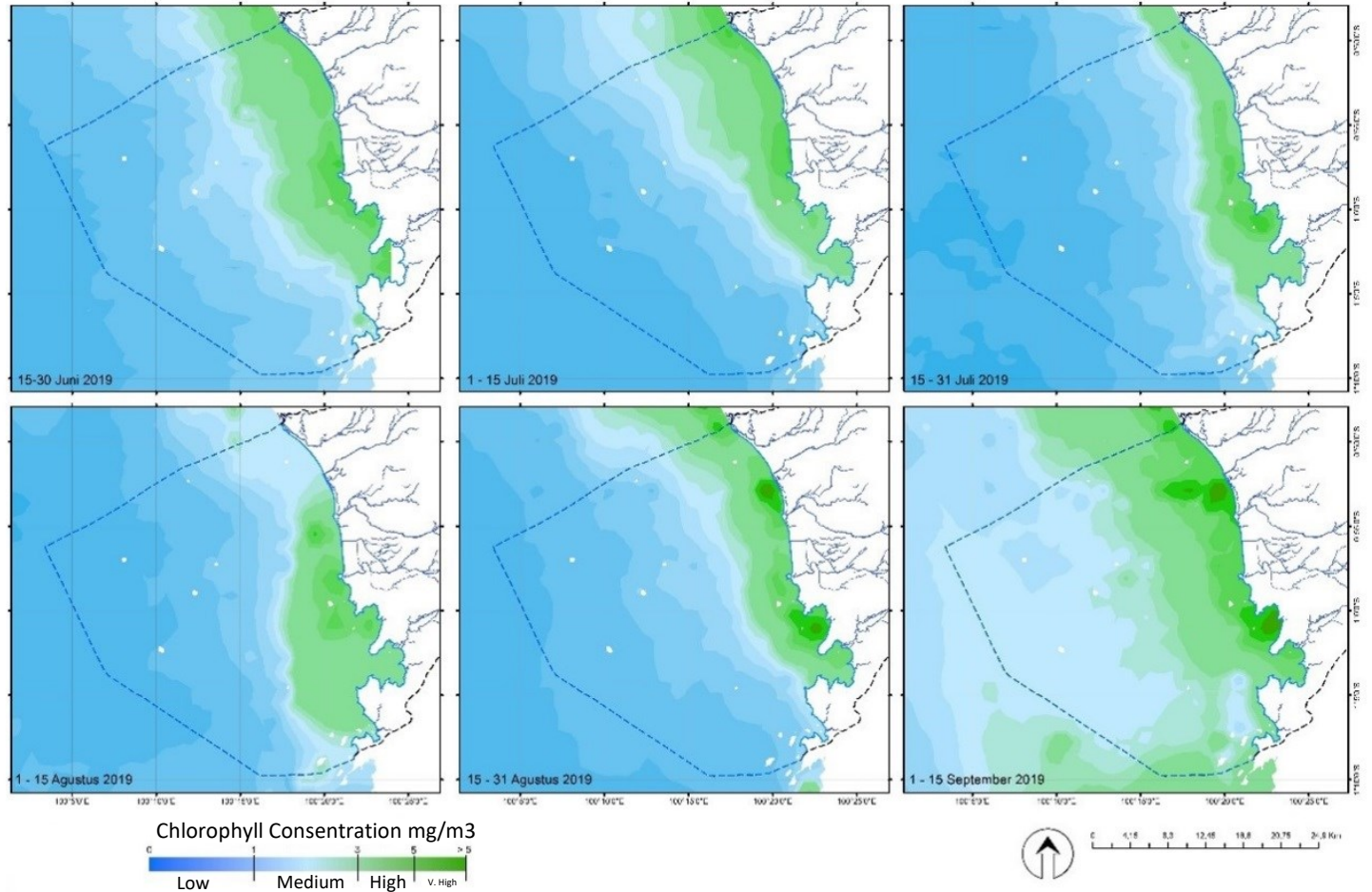

Fig. 4. Map of Average Chlorophyll-a Concentration per 15 Days in The Padang Sea During East Season 2019

However, the concentration of chlorophyll-a content in shallow water less than $100 \mathrm{~m}$ near the coast and less than 10 nautical miles from the shoreline was a water zone with high nutrient abundance. According to Xue et al. [2], a high increase in chlorophyll-a concentrations in the part of the waters near the coast in certain season periods was due to the high nutrient supply from the mainland directly through the river flow.

At the same time, high chlorophyll-a concentrations suggested that a global anomaly process was taking place in the Indian Ocean, resulting in the mass of water in the waters of Padang Sea being partly influenced by the mass of water from waters in the eastern boundary of the Indian Ocean. This mass of water moved with the movement of currents and winds on the surface of the Indian Ocean along the equator. The current flew eastward at high speed during the two transition periods between two seasons. Jet formation was accompanied by thermocline removal in where the jet came (the west) and sank (the east). This jet moved from Australia to Asia, the centre of low pressure between June and August [10], [19].

Map of average Chlorophyll-a Concentration (mg/m3) in Padang Sea during the east season in 2019 in Figure 5 shows how Padang Sea, as a part of Sumatra's west coast waters supplied by land nutrients had an area with very high chlorophyll concentrations on the coast, shown by deep green. Its presence could not spread evenly in the sea due to pressure from the mass movement of Indian Ocean water coupled with the occurrence of coastal upwelling that transported nutrient-rich water masses from the south waters of Java and Sunda Strait. Figure 5 is a map of average chlorophyll-a $(\mathrm{mg} / \mathrm{m} 3)$ concentration in the waters of Padang Sea during the east season in 2019.

The high content of chlorophyll-a at the end of the eastern season was influenced by the phenomenon of algal bloom that occurred in early September, making the chlorophyll-a content in sea waters very high. In addition, the southeast monsoon with the southwest monsoon towards the north from Australian causing the movement of currents to push the coast of Padang City was one of the factors causing the accumulation of algae on the coast (not spreading in the ocean).

Wyrtki [19] explained that bursts of strong west wind along the equator produced jets with narrow high-speed surfaces flowing along the equator from west to east across the entire Indian Ocean during the inter-seasonal transition, first during April-May and then reappearing during September-October. This wind moved the east currents strongly toward the equator, reaching average speeds exceeding 20 miles per day $(43 \mathrm{~cm} / \mathrm{sec})$. The narrow jet was about $500 \mathrm{~km}$ wide and symmetrical to the strongest equator between 60'EL and 90'EL where surface speed often exceeded 30 miles per day (64 $\mathrm{cm} / \mathrm{sec})$. A maximum value of 100 miles per day $(215$ $\mathrm{cm} / \mathrm{sec}$ ) was called Wyrtki jet.

Kämpf and Kavi [10] explained the mechanism of the phenomenon of positive IOD events triggered by the variability of SST in the eastern intertropical Indian Ocean from June to September. Much of the region's SST responses could be explained by the classical Ekman theory of wind-driven coastal upwelling. This research explained a simple theory about the SST response related to coastal upwelling events along the coast with limited horizontal boundaries. 


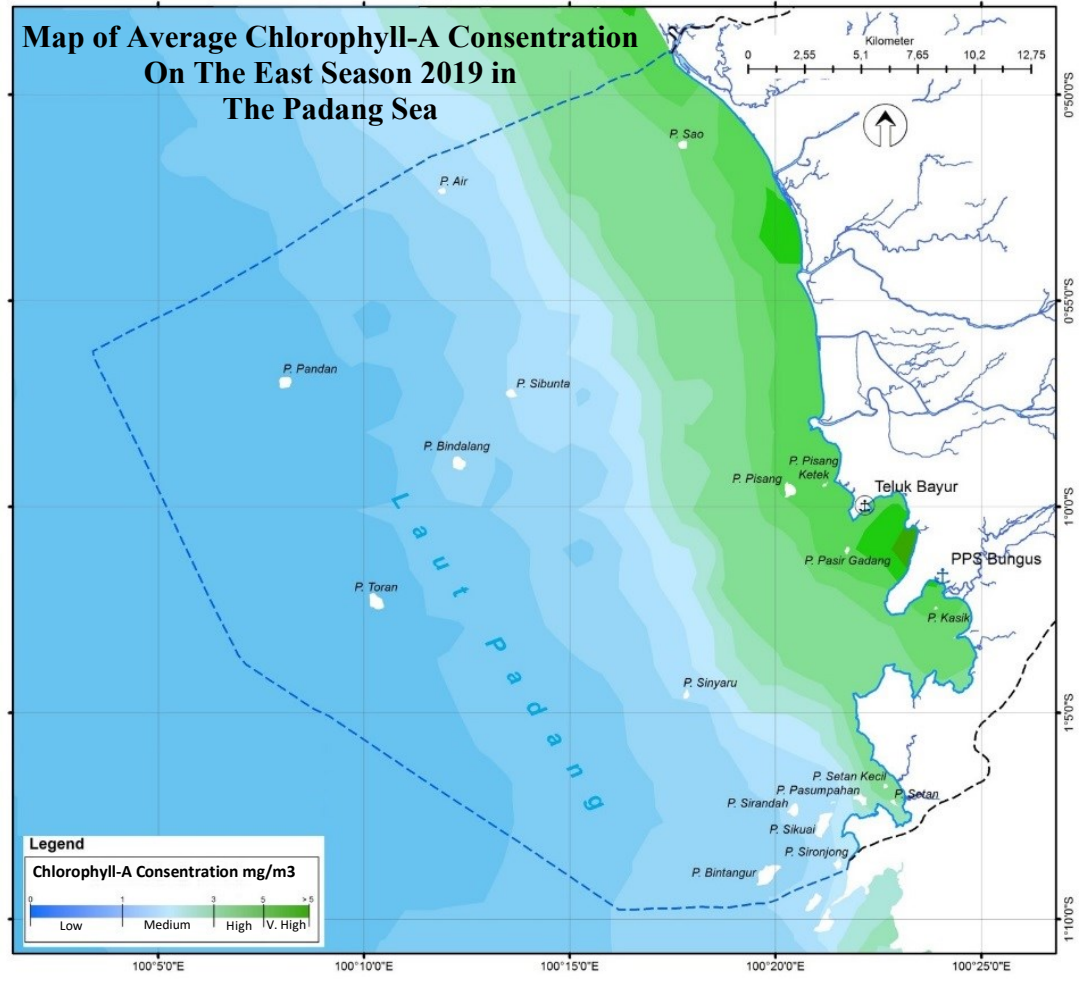

Fig. 5. Map of the Average Chlorophyll-a (mg/m3) Concentration in Padang Sea during the east season in 2019

In addition, research by Kämpf and Kavi described the surface circulation that formed in the western part of Sumatra and southern part of Java during the Positive IOD incident. This circulation pattern showed that the transportation of cold water at the equator with classic jet upwelling strengthened the negative (cold) SST anomaly in Sumatra's waters with its centre in the southwest. According to Susanto, Gordon, and Zheng [6], coastal upwelling of the southern offshore Java and of the western offshore of Sumatra was due to the influence of climate anomalies El Niño Southern Oscillation (ENSO).

In general, the trigger for an algal bloom was a combination of changes in several parameters in a body of water. Among them were chemical elements; such as Nitrogen, Phosphorus, and Silicate produced by domestic waste from river water flow into the sea waters which resulted in high concentration of nutrients in a body of water. This considerable amount of nutrients could accumulate in a relatively calm sea area; such as the bay area, due to the movement of concentrated currents and to certain places. The upwelling event as a natural factor also brought phytoplankton from the water to the surface, the influence of positive IOD climate anomalies and the lack of herbivorous zooplankton (copepods) that controlled the phytoplankton population [20], [21].

\subsection{Cross Validation}

The distribution pattern of SST and chlorophyll-a anomalies that occurred in the east season was based on the map of interpolation results. The determination of interpolation used the ordinary type of Kriging method (Figure 3,4,5). The results of distribution interpolate were almost evenly distributed throughout the waters but were highly concentrated in areas along the coast. Many previous studies had conducted the modelling of spatial distribution, chlorophyll-a deposits, and sea surface temperatures by means of interpolation. Some studies in the water area of West Sumatra used the Kriging Interpolation Method as conducted by Arta, Mubarak, and Nasution and Saputra [22], [23].

Nevertheless, before the interpolation model was used in this study, it was necessary to know the accuracy value of the modelling. One way to test the accuracy and error investigation of an interpolation model was to use cross validation [24], [25]. Cross validation was a statistical method that could be used to evaluate the performance of models or algorithms while maintaining the accuracy of estimates.

How to use this method was to delete one of the data and use the remaining sample as data to predict the value of related data that was eliminated using the model. This procedure was repeated for the next sample points until all sample points were validated. This method compared the measured and predicted values using all data, so that it could predict trends and auto-correlation models [26], [27], [28], [29].

Predicting values that could not be taken in full direct measurement of spatial data was the main objective of geostatistical interpolation [28]. This prediction was used by measuring the value owned by its neighbours spatially to be more optimal. Errors from predictions would produce certain error values (uncertainty). The smaller the error value, the higher the accuracy of the Geostatistical interpolation model (Figure 6).

In this study, the error value could be stated in RootMean-Square Error (RMSe), which was the square root of the average square of difference between the data sample values, and the sample values from independent sources whose accuracy was higher or the average value 
of the sum of the squares of errors. The value of RMSe obtained was 0.504 for SST and 0.363 for chlorophyll-a with an average/mean SST of -0.0005 and an average/mean of chlorophyll-a of -0.0039 . These results indicated that the use of the interpolation model of the distribution of Sea Surface Temperature and Chlorophyll-a content in Padang Sea using Kriging had a low error value or high accuracy.

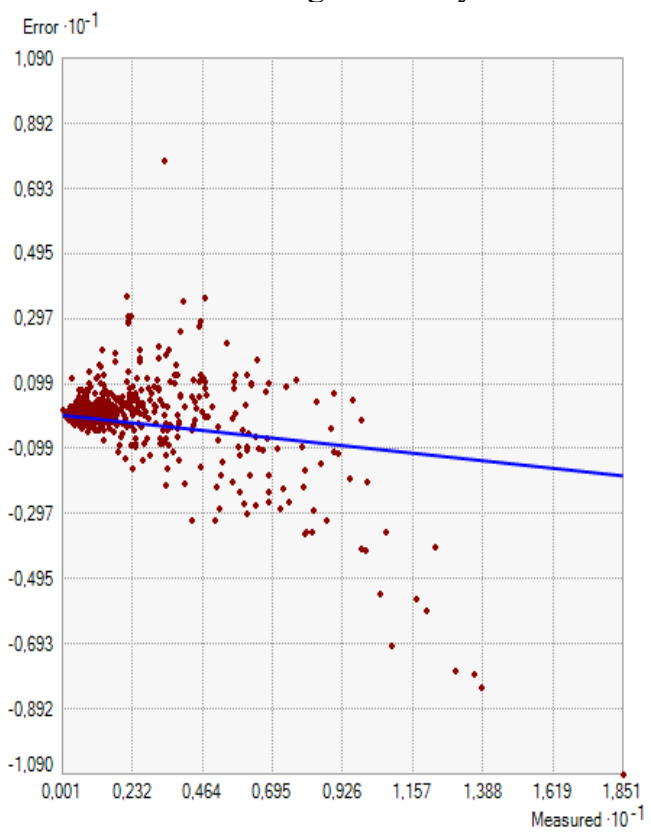

Fig. 6. Graph of Chlorophyll-a Error Cross Validation Value in the East Season in Padang Sea

\section{Conclusions}

The phenomenon of dry-phase Indian Ocean Dipole (IOD) or positive IOD originating from the Indian Ocean affected or disrupted the monsoon system at the location and time of study, so that the west coast of Sumatra, including Padang Sea, experienced extensive cooling during the final months of Australian winter (July-September). The average SST between AprilOctober 2019 was relatively cold, which was in the average temperature range of $18.5-22^{\circ} \mathrm{C}$. The average value of chlorophyll-a concentration in the east monsoon ranged between $0.252-18.5 \mathrm{mg} / \mathrm{m} 3$. Meanwhile, the distribution value of chlorophyll-a concentration was $1.028 \mathrm{mg} / \mathrm{m} 3$. The content of high chlorophyll-a concentrations in the water area of Padang was included in the Eutrophic category or waters that were rich in nutrients, so that algae plants grew well. The waters belonging to this category was a suitable location to find out the presence of fish with optimum temperature conditions. In some locations, hypereutrophic zones formed had experienced nutrient enrichment in very large amounts. The water conditions were less clear and caused algae blooms.

The authors are deeply grateful to MPPDAS, Faculty of Geography, Gadjah Mada University and the project was supported by LPDP as funding which has fully funded this research activity until the completion of this research.

\section{References}

[1] L. Hong, C. Wang, Y. Zhou, Z. Lin, X. Wang, and X. Song, "The distribution of chlorophyll a in the Southwestern Indian Ocean in summer," Shengtai Xuebao/ Acta Ecol. Sin., vol. 32, no. 14, pp. 4525-4534, 2012.

[2] L. Xue et al., "Aragonite saturation state in a monsoonal upwelling system off Java, Indonesia," J. Mar. Syst., vol. 153, pp. 10-17, 2016.

[3] Y. Zhang et al., "Monitoring of chlorophyll-a and sea surface silicate concentrations in the south part of Cheju island in the East China sea using MODIS data," Int. J. Appl. Earth Obs. Geoinf., vol. 67, no. February, pp. 173-178, 2018.

[4] M. F. Azis, "Gerak Air Dilaut," Oseana, vol. XXXI, no. 4, pp. 9-21, 2006. in Bahasa

[5] M. J. Babu, P. Geetha, and K. P. Soman, "MODIS-Aqua Data Based Detection and Classification of Algal Blooms along the Coast of India Using RLS Classifier," Procedia Comput. Sci., vol. 93, no. September, pp. 424430, 2016.

[6] R. D. Susanto, A. L. Gordon, and Q. Zheng, "Upwelling along the coasts of Java and Sumatra and its relation to ENSO," Geophys. Res. Lett., vol. 28, no. 8, pp. 1599-1602, 2001.

[7] R. D. Susanto, T. S. Moore, and J. Marra, "Ocean color variability in the Indonesian Seas during the SeaWiFS era," Geochemistry, Geophys. Geosystems, vol. 7, no. 5, pp. 1-16, 2006.

[8] K. Wyrtky, “UC San Diego,” Naga Rep., vol. 2, pp. 1-226, 1961.

[9] J.-M. Montero, G. Fernández-Avilés, and J. Mateu, Spatial and Spatio-Temporal Geostatistical Modeling and Kriging, I. The Atrium, Southern Gate, Chichester,West Sussex: JohnWiley \& Sons Ltd, 2015.

[10] J. Kämpf and A. Kavi, "SST variability in the eastern intertropical Indian Ocean - On the search for trigger mechanisms of IOD events," Deep. Res. Part II Top. Stud. Oceanogr., vol. 166, no. November 2018, pp. 64-74, 2018.

[11] O. Klemm and N. H. Lin, "What causes observed fog trends: Air quality or climate change?," Aerosol Air Qual. Res., vol. 16, no. 5, pp. 1131-1142, 2016.

[12] J. E. Simpson, Sea Breeze and Local Wind, 1st ed., vol. 1. Cambridge: Cambridge University Press, 1994.

[13] F. H. Lambert and M. J. Webb, "The Relationship between Land-Ocean Surface Temperature Contrast and Radiative Forcing," J. Clim., pp. 3239-3256, 2011.

[14] U. Tangke, J. C. Karuwal, M. Zainuddin, and A. Mallawa, "Sebaran Suhu Permukaan Laut dan Klorofil-a Pengaruhnya Terhadap Hasil Tangkapan Yellowfin Tuna (Thunnus albaceres) di Perairan Laut Halmahera Bagian Selatan.," J. IPTEKS PSP, vol. 2, no. 3, pp. 248-260, 
2015. in Bahasa

[15] B. C. Patra, M. Bhattacharya, A. Kar, B. K. Das, and P. K. Shit, "Assessment of Potential Marine Fishing Zone Using Geospatial Technologies at the Coastal Stretch of West Bengal, India," in Geospatial Infrastructure, Applications and Technologies: India Case Studies, 1st ed., N. L. Sarda, P. S. Acharya, and S. Sen, Eds. Springer Nature Singapore Pte Ltd., 2018, pp. 385-399.

[16] Z. Armi, E. Trabelsi, S. Turki, B. Béjaoui, and N. Ben Maïz, "Seasonal phytoplankton responses to environmental factors in a shallow Mediterranean lagoon," J. Mar. Sci. Technol., vol. 15 , no. 4, pp. 417-426, 2010.

[17] W. Yu, X. Chen, and Q. Yi, "Fishing ground distribution of neon flying squid (Ommastrephes bartramii) in relation to oceanographic conditions in the Northwest Pacific Ocean," J. Ocean Univ. China, vol. 16, no. 6, pp. 1157-1166, 2017.

[18] R. A. Vollenweider, F. Giovanardi, G. Montanari, and A. Rinaldi, "Characterization of the trophic conditions of marine coastal waters with special reference to the NW Adriatic Sea: Proposal for a trophic scale, turbidity and generalized water quality index," Environmetrics, vol. 9, no. 3, pp. 329-357, 1998.

[19] K. Wyrtki, “An Equatorial Jet in the Indian Ocean," Science (80-. )., vol. 181, no. 9, pp. 262-264, 1973.

[20] M. Makmur, "Pengaruh Upwelling Terhadap Ledakan Alga (Blooming Algae) Di Lingkungan Perairan Laut," in Prosiding Seminar Nasional Teknologi Pengolahan Limbah VI Pusat Teknologi Limbah Radioaktif-BATAN dan Pusat Penelitian Ilmu Pengetahuan dan Teknologi-RISTEK, 2008, pp. 240-245. In Bahasa

[21] T. S. Raza'i, I. P. Putra, M. . A. Suhud, and M. Firdaus, "Kelimpahan Kopepoda (Copepods) sebagai Stok Pakan Alami di Perairan Desa
Pengudang, Bintan," Intek Akuakultur, vol. 2, no. 1, pp. 63-70, 2018. In Bahasa

[22] F. H. Arta, Mubarak, and S. Nasution, "Sebaran Klorofil-a di Perairan Pantai Padang dan Pariaman Provinsi Sumatera Barat Menggunakan Citra Satelit Aqua Modis," J. Ilmu Lingkung., vol. 10, no. March 2015, pp. 128-137, 2016. In Bahasa

[23] H. Saputra, “Analisis Variabilitas Spasial dan Temporal Suhu Permukaan Laut dan Klorofil-A Menurut Musim Dengan Citra Aqua-MODIS untuk Menentukan Zona Tangkapan Ikan Cakalang (Studi Kasus Pada Kawasan Perairan Kabupaten Pesisir Selatan)," Universitas Negeri Padang, 2017. In Bahasa

[24] S. Wise, "Cross-validation as a means of investigating DEM interpolation error," Comput. Geosci., vol. 37, no. 8, pp. 978-991, 2011.

[25] K. Kang, C. Qin, B. Lee, and I. Lee, "Modified screening-based Kriging method with cross validation and application to engineering design,” Appl. Math. Model., vol. 70, pp. 626642, 2019.

[26] E. Respatti, R. Goejantoro, and S. Wahyuningsih, "Perbandingan Metode Ordinary Kriging dan Inverse Distance Weighted untuk Estimasi Elevasi Pada Data Topografi (Studi Kasus: Topografi Wilayah FMIPA Universitas Mulawarman)," J. Eksponensial, vol. 5, no. 2, pp. 163-170, 2014.

[27] ESRI, ArcGIS TM Geostatistical Analyst: Statistical Tools for Data Exploration, Modeling, and Advanced Surface Generation, ESRI White., no. August. New York: ESRI 380 New York St., Redlands, CA 92373-8100, USA, 2001

[28] K. Krivoruchko, "Introduction to Modeling Spatial Processes Using Geostatistcal Analyst," Esri, pp. 1-27, 2004.

[29] ESRI, "Geostatistical Analyst Tutorial Copyright," in Esri, 2010, p. 57. 